STUDIA PRAWNO-EKONOMICZNE, T. CXIV, 2020

PL ISSN 0081-6841; e-ISSN 2450-8179 $\quad$ s. 173-176

https://doi.org/10.26485/SPE/2020/114/9

Krzysztof WALISZEWSKI*

iD https://orcid.org/0000-0003-4239-5875

\title{
RECENZJA MONOGRAFII POD REDAKCJA NAUKOWA PROF. DR. HAB. MARKA MICHALSKIEGO PT. PIRAMIDY FINANSOWE A BEZPIECZEŃSTWO RYNKÓW, WYDAWNICTWO C.H. BECK, WARSZAWA 2019, SS. 268
}

Recenzowana monografia jest drugą w Polsce pozycją zwartą bezpośrednio poświęconą piramidom finansowym ${ }^{1}$, wpisując się jednocześnie w nurt publikacji o równoległym systemie bankowym (shadow banking) i parabankach ${ }^{2}$. Zespół autorski recenzowanej monografii stanowią pracownicy naukowi i doktoranci Katedry Prawa Gospodarczego Prywatnego, Katedry Prawa Finansowego i Ekonomii, Katedry Prawa Konstytucyjnego, Katedra Prawa Międzynarodowego i Europejskiego na Wydziale Prawa i Administracji Uniwersytetu Kardynała Stefana Wyszyńskiego w Warszawie oraz 1 osoba będąca wykładowcą Wydziału Nauk Ekonomicznych Uniwersytetu Warszawskiego. Zawartość poszczególnych rozdziałów monografii wraz z ich autorami jest następująca:

1. Sprzedawcy wiatru, czyli powtarzająca się historia piramid finansowych (prof. dr hab. Marek Michalski);

2. W poszukiwaniu alternatywy dla sądownictwa powszechnego: arbitraż jako metoda rozwiązywania sporów pochodnych na tle piramid finansowych? (dr Beata Gessel-Kalinowska vel Kalisz, dr Konrad Czech);

* Dr hab., prof. UEP, Uniwersytet Ekonomiczny w Poznaniu, Katedra Pieniądza i Bankowości; e-mail: Krzysztof.waliszewski@ue.poznan.pl

1 Pierwsza monografia naukowa to P. Masiukiewicz, Piramidy finansowe. Teoria. Regulacje. Praktyka, Wydawnictwo Naukowe PWN, Warszawa 2015.

2 W. Srokosz, Instytucje parabankowe w Polsce, Wolters Kluwer, Warszawa 2011; K. Waliszewski, G. Kotliński (red.), Instytucje parabankowe na rynku ustug bankowych w Polsce, CeDeWu, Warszawa 2012; J.K. Solarz, Shadow banking: systemowa innowacja finansowa, Społeczna Akademia Nauk, Warszawa 2014; K. Opolski, A. Gemzik-Salwach, M. Dwórznik, M. Podleśna, K. Wais, P. Zapadka, Sektor shadow banking w Polsce, CeDeWu, Warszawa 2015. 
3. Instrumenty państwa w zwalczaniu piramid finansowych (dr Barbara Giertych);

4. Schemat Ponziego, system argentyński i inne modele piramid finansowych (dr Justyna Dąbrowska);

5. Prezes Urzędu Ochrony Konkurencji i Konsumentów wobec piramid finansowych (dr Małgorzata Frysztak);

6. Piramidy finansowe w orzecznictwie Trybunału Sprawiedliwości Unii Europejskiej (dr Aleksandra Gawrysiak-Zabłocka);

7. Wyzwania regulacyjne zwalczania piramid finansowych na tle przypadku Albanii (dr Maciej Hulicki);

8. Ocena efektywności zakazów zakładania, prowadzenia i propagowania systemów promocyjnych typu piramida oraz organizowania systemu sprzedaży lawinowej jako narzędzi zwalczania piramid finansowych (mgr Ida Jóźwiak);

9. Społeczno-ekonomiczne determinanty funkcjonowania wybranych piramid finansowych w Europie (dr Robert Oktaba);

10. Fundacja jako przedsiębiorca stosujący system promocyjny typu piramida (dr Ewa Skibińska);

11. Piramida finansowa a marketing wielopoziomowy (dr Mariusz Stanik);

12. Ochrona konsumentów wobec zjawiska piramid finansowych - aspekty konstytucyjnoprawne (dr Aleksandra Syryt);

13. Piramidy finansowe $\mathrm{w}$ orzecznictwie sądów powszechnych (dr Tomasz Szczurowski);

14. Czy kryptowaluty są piramidą finansową? (mgr Sylwia Szutko);

15. Data mining a piramidy finansowe (dr Mateusz Tchórzewski).

Problematyka piramid finansowych poruszana w monografii jest aktualna i ważna szczególnie w kontekście wybuchających nowych afer finansowych z udziałem gospodarstw domowych i dyskusji nad regulacją sektora równoległej bankowości (shadow banking), do którego piramidy finansowe są zaliczane w kontekście zagrożeń, jakie stwarza ten sektor dla stabilności finansowej w ujęciu globalnym poprzez potencjalną materializację ryzyka systemowego. Historia piramid finansowych sięga XVIII w., gdzie we Francji szkocki ekonomista John Law założył towarzystwo akcyjne Kompanii Missisipi w celu eksploatowania pokładów złota w Luizjanie, którego w rzeczywistości tam nie było. Następnie początek XX w. dał się zapisać jako czas działania Charlesa Ponziego jako twórcy najbardziej znanej piramidy finansowej na świecie - schematu Ponziego z geometrycznie przyrastającą liczbą uczestników systemu. Współczesny kryzys finansowy (2007-2009) ujawnił, budowaną przez blisko 50 lat, dotychczas 
największą na świecie piramidę finansową współtwórcy NASDAQ - pierwszej na świecie całkowicie elektronicznej giełdy papierów wartościowych - Bernarda Madoffa, który oszukał inwestorów na 65 mld USD, za co został w 2009 r. skazany na 150 lat więzienia. Historia gospodarcza świata zna jeszcze piramidy finansowe m.in. w Rosji (MMM) i Albanii, gdzie upadłości piramid finansowych doprowadziły do chaosu, niepokojów społecznych, w których straciło życie 2 tys. osób, a w konsekwencji do upadku rządu. W przypadku Polski najbardziej znane oszustwa typu piramida finansowa to Bezpieczna Kasa Oszczędności Lecha Grobelnego, Galicyjski Trust Kapitałowo-Inwestycyjny, Warszawska Grupa Inwestycyjna, Finroyal, Amber Gold. Autorzy monografii słusznie zadają sobie pytanie, jakie mechanizmy sprawiają, że historia piramid finansowych powtarza się, potencjalni klienci nie uczą się na błędach poprzedników, kolejne piramidy są coraz bardziej wyrafinowane i mają większą skalę oszukanych osób i poniesionych przez nie strat, a państwo nie jest w stanie zapewnić skutecznej ochrony gospodarstw domowych konsumentów przed działalnością piramid finansowych?

Autorzy monografii definiują piramidę finansową jako przedsięwzięcie, które z założenia oferuje ponadprzeciętne zyski i opiera się na dopływie środków od coraz to nowych uczestników systemu, dzięki czemu możliwa jest realizacja wypłat i zysków pozostałych uczestników. W poszczególnych rozdziałach monografii autorzy przytaczają różne przykłady piramid finansowych od początku ich powstania aż po współczesność - Kampanię Missisipi Johna Lawa (XVIII w., Francja), Securities Exchange Company (SEC) Charlesa Ponziego (lata 20. XX w., USA), fundusz hedgingowy Bernard L. Madoff Investment Securities LLC (BLMIS) Bernarda Lawrence'a Madoffa (1960-2009, USA), piramidy finansowe w Albanii, sprzedaż lawinową, system argentyński (konsorcjalny), piramidy na rynkach finansowych.

Zaprezentowane przez autorów monografii podejście jest prawidłowe wobec złożoności problemu, jakim jest działalność piramid finansowych, i ma charakter interdyscyplinarny, ponieważ obejmuje aspekty regulacyjne, ekonomiczno-finansowe i społeczne. Nie bez znaczenia jest fakt, że znacząca część zespołu autorskiego, poza działalnością naukową, to praktycy gospodarczy, przez co prezentowane przez nich treści są uzupełnione o wiedzę praktyczną.

$\mathrm{W}$ aspekcie normatywnym autorzy poruszają takie zagadnienia, jak ochrona konsumenta, skuteczne regulacje prawne mające na celu wykrywanie, penalizację i dezaktywację piramid finansowych w Polsce i UE, działalność Prezesa UOKiK w zakresie przeciwdziałania piramidom finansowym, orzecznictwo są- 
dowe w Polsce i UE dotyczące piramid finansowych oraz arbitraż jako alternatywa dla sądownictwa powszechnego.

W aspekcie ekonomiczno-finansowym autorzy słusznie analizują przyczyny i mechanizm działania, a także skutki finansowe upadłości piramid finansowych. Ponadto aspekty ekonomiczno-finansowe obejmują takie zagadnienia, jak marketing wielopoziomowy (multi-level-marketing, MLM), działalność fundacji, nowoczesne technologie (blockchain, bitcoin) czy datamining w kontekście działalności piramid finansowych. Nowoczesne technologie zmieniają formy działania piramid finansowych, choć sam ich mechanizm pozostaje od wieków bardzo podobny. Piramidy finansowe niezależnie od miejsca i czasu działania oparte są zawsze na dwóch zasadniczych elementach, z których jeden stanowią czynniki behawioralne (naiwność, zachowania stadne, uleganie agresywnej reklamie, chciwość), a drugi element to brak wiedzy finansowej i asymetria informacyjna między uczestnikami a twórcami piramid finansowych oraz celowa dezinformacja i wprowadzanie klientów w błąd, czyniąca inwestorów podatnych na różnego rodzaju obietnice (,sprzedawcy wiatru”), które przy obiektywnej ocenie okazują się obietnicami bez pokrycia obarczonymi ogromnym ryzykiem. Dodatkowym czynnikiem kreującym możliwość powstania w danym czasie i miejscu piramid finansowych jest brak lub niedostateczne regulacje prawne i słabość nadzoru finansowego.

Aspekty społeczne analizy piramid finansowych obejmują koszty społeczne związane m.in. z utratą oszczędności przez inwestorów-gospodarstwa domowe, ze spadkiem zaufania publicznego do państwa, które nie potrafiło ich ochronić przed oszustami, a także całego systemu finansowego i instytucji finansowych działających uczciwie i legalnie.

Recenzowana monografia jest pozycją ciekawą i wartościową tak dla prawników, jak i ekonomistów czy socjologów, a także studentów powyższych kierunków, ponieważ pozwala wyjaśnić w sposób interdyscyplinarny złożone zagadnienie przyczyn i mechanizmów działania oraz skutków upadłości piramid finansowych, a także podejmuje zagadnienia efektywnej ochrony konsumenta i skutecznych regulacji prawnych zapobiegających powstawaniu i dezaktywacji piramid finansowych. 